\title{
Towards Business Intelligence Success Measurement in an Organization: A Conceptual Study
}

\author{
Aws AL-Okaily ${ }^{1}$, Teoh Ai Ping ${ }^{1}$, Manaf Al-Okaily ${ }^{2}$ \\ ${ }^{1}$ Graduate School of Business, Universiti Sains Malaysia, Malaysia \\ ${ }^{2}$ School of Business, Jadara University, Irbid, Jordan \\ Awsokaily@student.usm.my
}

\begin{abstract}
The implementation of Business Intelligence System (BIS) has grown rapidly world-wide in recent years to enable organizations to compete in the rigorous business environment. To date, several organizations are still struggling to derive BIS benefits as its implementation was not a successful as expected. The lack of measurement is believed to be a main reason for the BIS failure. Towards this issue, a theoretical model was proposed in this article grounded on the Information System Success Model (ISSM) to BIS success measurement at the organizational level. The authors argued that system quality, information quality, service quality, collaboration quality and process quality will individually and jointly influence both perceived usefulness and user satisfaction, influence perceived usefulness on user satisfaction and thereby these factors are antecedences of organizational benefits. This conceptual paper has synthesized knowledge from relevant literature and has offered a holistic understanding of the BIS success assessment in an organization. To the best of our knowledge based on a comprehensive literature review, our present paper is the first of its kind to propose a theoretical model to BIS success measurement in an organization. It also extends the ISSM to use in BIS filed at the organizational level of analysis.
\end{abstract}

Keywords: Business Intelligence System, BIS Success, Information System Success Model. 


\section{Introduction}

At the start of the 21st century, organizations faced prominent challenges such as stringent competition, continuous technology improvements and a large volume of data. To succeed in the face of these challenges, organizations today require special Information Systems (IS) such as business intelligence to perform a variety of causal analysis of big data to make the data available to decision-makers and analysts at various levels within an organization (Lim \& Teoh, 2020). IBM Institute for Business Value conducted a survey among 3000 respondents in 100 countries and reported competitive value gains from advanced analytics functions (Debortoli, Müller, \& Brocke, 2014). Naturally, BIS has dominated the innovated technology priority list of CIOs in today's digitized world (Chen \& Lin, 2020). The concept of BIS is known as an integrated set of tools, technologies and programmed products that are used to collect, integrate, analyze and make data available (Torres \& Sidorova, 2019).

Specifically, BIS includes several technological elements (Visinescu, Jones, \& Sidorova, 2017; Ain, Vaia, DeLone, \& Waheed, 2019; Khatibi, Keramati, \& Shirazi, 2020) including Online Analytical Processing (OLAP), data warehouse and dashboard. OLAP allows users to apply various operations including aggregation, filtering, roll up and drill down for details; it also supports multi-dimensional analysis in real-time. Data warehouse enables the in-depth analysis of detailed data that has been gathered and cleaned from multiple sources. Dashboard allows the user to track the business's key performance indicators, which can then be displayed in the form of charts, graphs, ad hoc reports and widgets. Based on that, it is an umbrella term that covers a wide range of techniques, tools, concepts, processes and methods used to consolidate, analyze and provide information access in order to improve business decision making (Khatibi et al., 2020).

Notwithstanding the global market for BIS in recent years is vibrant and grown very fast, which is predicted to account for $\$ 22.8$ billion by end of year 2020 (Ain et al., 2019), organizations have still complained that BIS is not in accordance with the expected results and benefits (Niño, Niño, \& Ortega, 2020; Ain et al., 2019; Visinescu et al., 2017; Villamarín-García, 2020; Ranjbarfard \& Hatami, 2020; Božič \& Dimovski, 2019). A survey conducted by Gartner Inc. indicated that about 70 to 80 percent of BIS projects fail (Ranjbarfard \& Hatami, 2020). Similarly, others estimated that approximately 70 to 80 percent of BIS fail due to both technological and managerial issues (Villamarín \& Diaz Pinzon, 2017; Ain et al., 2019). In another case, Pham, Mai, Misra, Crawford and Soto (2016) reported a rate of failure ranged between 65 and 70 percent. Additionally, developing countries all over the world, including Jordan, have been challenged to realize the BIS benefits. The lack of measurement is believed to be a main reason for the BIS failure. The measurement of the success of BIS is theoretical and managerial challenging and complicated for several organizations (Dedić \& Stanier, 2016; Ain et al., 2019).

As a result, organizations today are concerned with knowing the benefits return of 
BIS investments. Knowing the BIS benefits is not only useful for avoiding failure, but for knowing where to prioritize time and money, because such knowledge can also assist in budgeting and scheduling (Visinescu et al., 2017). Looking at the academic literature, success factors through which BIS contributes to achieving organizational benefits has not been sufficiently explored. This is because the study of Critical Success Factors (CSFs) of BIS implementation remains poorly understood (El-Adaileh \& Foster, 2019; Pham et al., 2016). Undeniably, an understanding of the BIS success factors aids organizations to optimize their efforts and scarce resources through centering on those critical factors that are most likely to help successful BIS implementation. Consequently, further research to shed more light on CSFs affecting the implementation BIS is desirable. Against this background, a theoretical model was proposed in this conceptual article with a focus on BIS success measurement at the organizational level. Like previous works in this field, we anchored on DeLone and McLean IS success model (which we will refer to as success model or ISSM) as a sound basis in this conceptual paper.

The remainder of this article is arranged as follows. The next section presents the theoretical background related to this work. The theoretical model is discussed in the third section. The fourth section presents the hypotheses proposed in line with related prior studies. The fifth section presents the methods used in this paper followed by the conclusion of this paper in the last section.

\section{Theoretical Basis}

In the mid-90s, BIS emerged to confirm the significance of integration, analysis collection and interpretation information and how these processes can assist businesses to make relevant decisions and have greater understanding of market trends, thus leading to increased profit, reduced costs, improved productivity and enhanced competitiveness within an organization. However, organizations are still undecided on whether BIS investments translate into valuable organizational benefits due to their high failure rate. Therefore, organizations now struggle to measure BIS success (Dedić \& Stanier, 2016). The related literature indicated that IS success is an elusive phenomenon that can only be explained by a multi-dimensional construct (Jeyaraj, 2020). In spite of the usefulness and unique qualities of BIS, the factors responsible for the BIS success remain poorly understood.

To address this problem, DeLone and McLean (1992) based on comprehensive literature review, proposed multi-dimensional model to measure IS success. In their original model, they identified six interrelated success factors, which are system quality, information quality, use, satisfaction, individual and organizational impact. This model suggests that a users' behavior (actual use) and their attitude (satisfaction) are influenced by both information quality and system quality. Behavior is affected by users' attitude and their attitude is formed from behavior. Eventually, behavior and attitude produce an individual impact and in turn organizational impact. This 
model has been widely accepted and cited as a theoretical foundation to IS success measurement (Al-Okaily, Rahman, Al-Okaily, Ismail, \& Ali, 2020; Gharaibeh \& Gharaibeh, 2020; Al-Hattami, 2021).

Nonetheless, several scholars have critiqued and proposed an extension of the model considering it not a completed model. For example, Pitt, Watson, \& Kavan (1995) criticized that the model does not cover service quality which is a key factor in IS success. A later study by Seddon and Kiew, (1996) replaced use with usefulness, arguing that usefulness is a meaningful factor of success in compulsory and voluntary settings, while system use alone was not a success factor. Thus, the importance of the system was incorporated as a new factor, and other IS impact factors were ignored. In his paper, Seddon (1997) indicated that perceived usefulness is a success factor rather than usage, which is a behavior. Others claimed that there are additional stakeholders to consider, and that IS impact is not limited only to individuals and organizations such as consumers, work groups, industry and society.

In light of the dramatic changes of technology practice and aforementioned criticisms for model improvement, DeLone and McLean later in 2003 offered an updated version of their model because of difficulties in recognizing the concept of system use, resulting in incorporate intention to use with system use construct. In the updated version, they included service quality to capture the importance of IS support and noted that it an essential factor to overall IS success evaluation (DeLone \& McLean, 2003). The updated version also grouped the individual and organizational impact into the net benefits construct. The last refinement is including feedback links from net benefits to antecedent factors. Figure 1 displays the updated ISSM, which suggested that quality dimensions separately and together impact usage dimensions. Meanwhile, usage dimensions impact each other and have a joint impact on net benefits. The benefits reflect positively or negatively on usage dimensions.

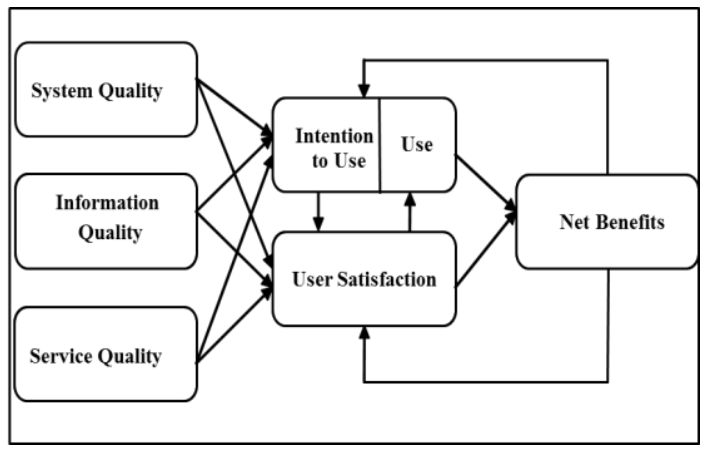

Fig. 1: Information System Success Model (2003).

Unquestionably, this model has considerable and significant contributions to related literature. First, it introduces a suitable basis for more conceptual and empirical studies (Petter, DeLone, \& McLean, 2008). Second, it introduces a 
theoretical framework to classify the recognized factors of IS success domain that have been proposed in the prior studies (Gable, Sedera, \& Chan, 2008). Third, their model suggests temporary and casual interrelationships between the specified factors (Wu \& Wang, 2006). Fourth, their success model can be applied at multiple levels of analysis depending on the research purpose (Gorla, Somers, \& Wong, 2010). And lastly, it is exceedingly used in IS success field (Urbach, Smolnik, \& Riempp, 2010). For these reasons, it has been extensively adopted as a theoretical lens in the IS success assessment literature.

Nevertheless, past studies seldom used this model to evaluate the BIS benefits. For example, Gonzales and Wareham (2019) used the success model to test the effect of quality dimensions on system use, satisfaction and individual impact in BIS context among Peruvian firms. However, their findings reported no impact of system use with other dimensions of the model. In another study, Gaardboe, Nyvang and Sandalgaard, (2017) adopted the success model to explore BIS success in 12 Danish public hospitals. Generally, their model has a good predictive value; however, they revealed the impact of system use on others factors to be extremely low. These studies explained the lack of significant impact of use with other factors as the users do not have an alternative system in mandatory settings to process information.

Interestingly, no study has yet used success model to measure BIS from an organizational perspective. This is a gap that has been recognized in calls for theoretically-grounded research on BIS benefits. To bridge this research gap, our current work has developed a theoretical model depended on ISSM to evaluate BIS from an organizational perspective. The next section provides the theoretical model proposed in the current study.

\section{Theoretical Model}

Even though the ISSM has been updated, several researchers noted that it needs further validation to be used as a theoretical basis for IS success evaluation (Wu \& Wang, 2006; Roy \& Balaji, 2015; Chang \& Chen, 2009; Wang, 2008). Their model also should also be extended further with other success factors to introduce an inclusive model in an organizational context (Al-Okaily, Al-Okaily, Shiyyab, \& Masadah, 2020; DeLone \& McLean, 2016; Urbach \& Müller, 2012) particular in BIS domain (Gaardboe et al., 2017). The present research has proposed a theoretical model (see Figure 2) based on ISSM to BIS success evaluation in an organizational context. However, we made some modifications to suit the BIS specificities. First of all, we included two key success factors from related literature into our proposed model, which are collaboration quality and process quality.

Although some authors view that system quality factor has already covered collaboration and process aspects, others argued that these factors are separate and distinct (Gaardboe et al., 2017; Chen, Chen \& Capistrano, 2013; Costa, Aparicio, \& Raposo, 2020). Another modification was adopting perceived usefulness construct 
instead of system usage, given that system usage is a success factor in case system usage is voluntary. Likewise, in line with this modification, numerous authors in (Seddon \& Kiew, 1996; Lutfi et al., 2021; Seddon, 1997; Wu \& Wang, 2006; Gorla et al., 2010; Al-Okaily, Al-Okaily, Shiyyab, \& Masadah, 2020; Ifinedo, Rapp, Ifinedo, \& Sundberg, 2010) confirmed that system usage cannot be considered as a suitable indicator of success when use is involuntary. Evidence in the literature also indicates that system use can be considered as an antecedent factor of success rather than a success factor (Ifinedo et al., 2010; Gable et al., 2008). The last modification was ignoring the feedback links to avoid model complexity. In the following section, the hypotheses development for this paper are discussed.

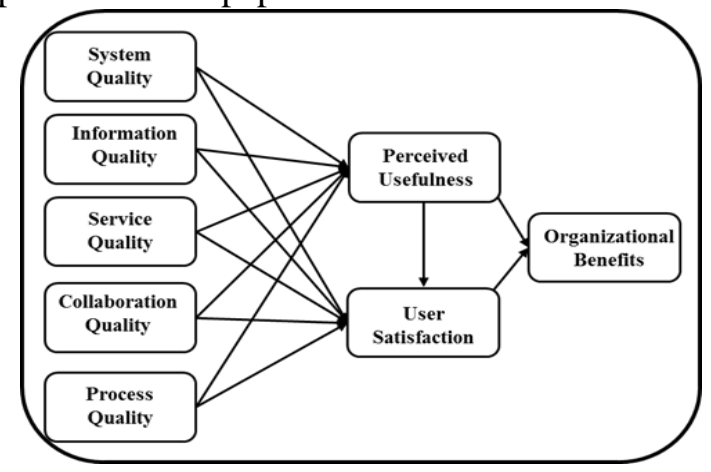

Fig. 2: Theoretical Model.

\section{Research Proposition}

As mentioned earlier, our model assumed that system quality, information quality, service quality, collaboration quality and process quality will individually and jointly impact perceived usefulness and user satisfaction, impact perceived usefulness on user satisfaction and eventually these dimensions will be viewed as antecedences of organizational benefits.

\subsection{System Quality}

Specifically, system quality is regarded as a system performance measurement that includes integration, ease of use, functionality, reliability, responsiveness and flexibility (DeLone \& McLean, 2016). Previously, it has been accepted that the high level of system quality is a key indicator of success of IS within any organization (Alawaqleh, 2021; Al-Okaily, Al-Okaily, Ping, Al-Mawali, \& Zaidan, 2021; Lutfi, Al-Okaily, Alsyouf, Alsaad, \& Taamneh, 2020). The literature found that system quality is an important determinant in perceived usefulness and user satisfaction (Seddon \& Kiew, 1996; Seddon, 1997). However, a recent study by Chen, Jubilado, Capistrano and Yen (2015) found insignificant impact of system quality on perceived usefulness and user satisfaction. Therefore, the mixed results in this regard lead us to formulate the next hypotheses: 
H1. System quality will have a positive influence on perceived usefulness.

H2. System quality will have a positive influence on user satisfaction.

\subsection{Information Quality}

In contrast to system quality, information quality represents feature information that are produced from system (DeLone \& McLean, 2016; Le, Nguyen, Bui, \& Dang, 2020; Martono, Nurkhin, Mukhibad, Anisykurlillah, \& Wolor, 2020). These features are relevance, accuracy, completeness, reliability, conciseness, currency and precision of information (DeLone \& McLean, 2016). Past research empirically supported the positive and significant influence of information quality on both perceived usefulness and user satisfaction (Chen et al., 2015; Rana, Dwivedi, Williams, \& Weerakkody, 2015). Equally important, some researchers found insignificant impact of information quality on usefulness (Cidral Oliveira, Felice, \& Aparicio, 2018; Kulkarni, Ravindran, \& Freeze, 2006) as compared to satisfaction (Chen, Chen, \& Capistrano, 2013). Hence, these incompatible findings lead us to propose the next hypotheses:

H3. Information quality will have a positive influence on perceived usefulness.

H4. Information quality will have a positive influence on user satisfaction.

\subsection{Service Quality}

The ultimate user computing advancement placed IS enterprises in the dual role of both information and service provider. Service provider or quality indicates to support that users received from IS department with respect to responsiveness, assurance, and empathy (DeLone \& McLean, 2016; Akob, Yantahin, Ilyas, Hala \& Putra, 2021). Many related works have proven that good service quality predict perceived usefulness and also user satisfaction such as (Floropoulos, Spathis, Halvatzis, \& Tsipouridou, 2010; Chen et al., 2013). Meanwhile, others authors did not find a significant influence of service quality on usefulness (Gorla \& Somers, 2014; AlFraihat, Joy, \& Sinclair, 2020), in turn, between service quality and satisfaction (Chen et al., 2015). Thus, these conflicting findings lead us to suggest the following two hypotheses:

H5. Service quality will have a positive influence on perceived usefulness.

H6. Service quality will have a positive influence on user satisfaction.

\subsection{Collaboration Quality}

The technology developments also have opened the window for collaboration efforts to be more efficient and effective. Collaboration quality is known as facilitating better knowledge integration and exchange, decision making, and resource sharing (Urbach et al., 2010; Chen et al., 2013). Some empirical studies have found that collaboration quality has a positive influence on the perceived usefulness and user satisfaction (Chen et al., 2013). Otherwise, there are other works which reported an insignificant influence of collaboration quality on both perceived usefulness and user 
satisfaction (Cidral et al., 2018). Thus, the inconsistent findings motivate us develop the following two hypotheses:

H7. Collaboration quality will have a positive influence on perceived usefulness.

H8. Collaboration quality will have a positive influence on user satisfaction.

\subsection{Process Quality}

Apart from system quality, process quality covers how the BIS supports an organization's business processes. It is usually assessed in terms of flexibility, timely reliability, accuracy, and other criteria to enable business operations to be more efficient and effective (Chen et al., 2013; Urbach et al., 2010). An empirical study conducted by Chen et al. (2013) demonstrated that perceived usefulness is positively and significantly influenced by process quality. On the other hand, some authors have found process quality and user satisfaction to be positively related (Costa, Aparicio, \& Raposo, 2020; Urbach et al., 2010). Thus, we extend this relation to a new context, namely BIS, and hypothesize the following:

H9. Process quality will have a positive impact on perceived usefulness.

H10. Process quality will have a positive impact on user satisfaction.

\subsection{Perceived Usefulness}

In addition, perceived usefulness is a critical index in this regard (Hua, Ramayah, Ping, \& Jun-Hwa, 2017; Xin, Ramayah, Soto-Acosta, Popa, \& Ping, 2014). It is defined as "the degree to which a person believes that using a particular system would enhance his or her job performance" (Davis, 1989, p.320). The positive impact of perceived usefulness on user satisfaction has been empirically confirmed by several researchers such as (Chen et al., 2015; Floropoulos et al., 2010) and organizational impact (Wibowo \& Sari, 2018; Almazán, Tovar, \& Quintero, 2017; Park, Ciganek, \& Lim, 2011). On the other hand, studies conducted by (Sabherwal, Jeyaraj, \& Chowa, 2006; Ghobakhloo \& Tang, 2015; Gorla \& Somers, 2014) revealed an insignificant effect of usefulness on satisfaction. Similarly, others showed that there was no significant correlation between usefulness and organizational impact (Alsabawy, Cater-Steel, \& Soar, 2013; Choi, Rho, Park, Kim, Kwon \& Choi, 2013; Park, Sharman, Rao \& Upadhyaya 2009). Empirical evidence as mentioned above is mixed, as a result, the following two hypotheses are assumed:

H11. Perceived usefulness will have a positive influence on user satisfaction.

H12. Perceived usefulness will have a positive influence on organizational benefits.

\subsection{User Satisfaction}

One major factor that caused BIS failure is the lack of end-user satisfaction. The concept of satisfaction concerns the extent to which users feel the BIS meets their requirements. It is direct antecedent factor and predictor of organizational impacts (DeLone \& McLean, 1992). A number of previous works have shown that satisfaction 
influences organizational impact in numerous technology contexts (Aldholay, Isaac, Abdullah, \& Ramayah, 2018; Djong, Kamdjoug, \& Wamba, 2018; Chou \& Hong, 2013). From another angle, others showed that satisfaction has not been shown to have a positive effect on organizational impacts (Al-Hattami, 2021; Pérez-Mira, 2010). Another study found similar results, in that satisfaction is weakly linked with performance of decision-making (Yuthas \& Young, 1998). These conclusions allow us to suppose the following hypotheses:

H13. User satisfaction will have a positive influence on organizational benefits.

\section{Methodology}

Through the above discussion, our present work implicitly assumes that the interrelationships determined in our theoretical model are paradoxical across various kinds of users, systems and organizations. These inconsistent results can be caused by differences in economic conditions between developed and developing countries, system context and regulatory environments across countries. Further studies are clearly needed in an organizational context. Therefore, we extend these prior works to evaluate BIS success at the organizational level. To better understand the critical factors of BIS success in an organizational context, a theoretical model was constructed from interdisciplinary sources of the related literature about BIS. The research method of this paper relied on a comprehensive literature review from a wide range of publications. The publications reviewed included full-text documents, journals and book chapters. These publications were taken from reputable online databases such as Google Scholar, Web of Science, Scopus and Science Direct. The advanced search used index terms and keywords such as Business Intelligence System, Business Intelligence Success Information System Success Model, DeLone and McLean Model, Critical Success Factors and Organizational Level. The sources were not restricted to a specific context but took into account worldwide BIS progress across developing and developed countries. This is because the subject of BIS success is a relatively new topic and also due to a dearth of knowledge in this domain.

\section{Conclusion}

The rapid proliferation of technology has resulted in the production of a large amount of data within organizations and has brought considerable concern on research study opportunities in BIS area. Although the BIS implementations are complex, high cost and require wages, infrastructure, license software and training, organizations today across the world are adopting BIS for promoting business and obtaining an advantage over competitors. Unfortunately, several stakeholders and organizations found that BIS implementation often fail. Those failures produce organizational problems such as wasted time, resources, and opportunity cost of invested capital. Therefore, we developed in this conceptual paper a new theoretical model, whose core principle is grounded on the ISSM to evaluate BIS in an organizational context. There are two 
major reasons for BIS success measurement in this conceptual paper. The first reason is to prove it is worth the investment and that it has actual benefits. The second reason is to ensure that BIS satisfies the users' needs and it is efficient. The proposed theoretical model combined eight success factors: system quality, information quality, service quality, collaboration quality, process quality, perceived usefulness, satisfaction and organizational benefits. It has been established from the literature review that all the factors adopted in our model are very necessary to look at. This conceptual paper presents good theoretical platform for empirical grounded study on $\mathrm{BIS}$ area. This work is still in progress as $\mathrm{PhD}$ project; therefore, a practical empirical analysis will be accompanied in the next stage to validate the effect of factors included in our proposed model.

\section{References}

Ain, N., Vaia, G., DeLone, W. H., \& Waheed, M. (2019). Two decades of research on business intelligence system adoption, utilization and success-A systematic literature review. Decision Support Systems, 125, 113113.

Akob, M., Yantahin, M., Ilyas, G. B., Hala, Y., \& Putra, A. H. P. K. (2021). Element of Marketing: SERVQUAL Toward Patient Loyalty in the Private Hospital Sector. The Journal of Asian Finance, Economics, and Business, 8(1), 419-430.

Alawaqleh, Q. A. (2021). The Effect of Internal Control on Employee Performance of Small and Medium-Sized Enterprises in Jordan: The Role of Accounting Information System. The Journal of Asian Finance, Economics and Business, 8(3), 855-863.

Aldholay, A. H., Isaac, O., Abdullah, Z., \& Ramayah, T. (2018). The role of transformational leadership as a mediating variable in DeLone and McLean information system success model: The context of online learning usage in Yemen. Telematics and Informatics, 35(5), 1421-1437.

Al-Fraihat, D., Joy, M., \& Sinclair, J. (2020). Evaluating E-learning systems success: An empirical study. Computers in Human Behavior, 102, 67-86.

Al-Hattami, H. M. (2021). Validation of the D\&M IS success model in the context of accounting information system of the banking sector in the least developed countries. Journal of Management Control, 1-27.

Almazán, D. A., Tovar, Y. S., \& Quintero, J. M. M. (2017). Influence of information systems on organizational results. Contaduría y Administración, 62(2), 321-338. 
Al-Okaily, A., Abd Rahman, M. S., Al-Okaily, M., Ismail, W. N. S. W., \& Ali, A. (2020). Measuring success of accounting information system: Applying the DeLone and McLean model at the organizational level. Journal of Theoretical and Applied Information Technology, 98(14), 2697- 2706.

Al-Okaily, A., Al-Okaily, M., Ai Ping, T., Al-Mawali, H., \& Zaidan, H. (2021). An empirical investigation of enterprise system user satisfaction antecedents in Jordanian commercial banks. Cogent Business \& Management, 8(1), 1918847.

Al-Okaily, A., Al-Okaily, M., Shiyyab, F., \& Masadah, W. (2020). Accounting information system effectiveness from an organizational perspective. Management Science Letters, 10 (16), 3991-4000.

Al-Okaily, M. M., \& Rahman, M. S. A. (2017). The impact of implementing web trust principles on the efficiency of accounting information system in commercial banks at Jordan. Journal of Business and Management, 19(7), 71-80.

Al-Okaily, M., Abd Rahman, M. S., \& Ali, A. (2019). Factors affecting the acceptance of mobile payment systems in Jordan: The moderating role of Trust. Journal of Information System and Technology Management, 4(15), 16-26.

Alsabawy, A. Y., Cater-Steel, A., \& Soar, J. (2013). IT infrastructure services as a requirement for e-learning system success. Computers \& Education, 69, 431-451.

Al-Okaily, M., Alqudah, H., Matar, A., Lutfi, A. A., \& Taamneh, A. (2020). Impact of Covid-19 pandemic on acceptance of elearning system in Jordan: A case of transforming the traditional education systems. Humanities and social Sciences Review, 6(4), 840-851.

Božič, K., \& Dimovski, V. (2019). Business intelligence and analytics for value creation: The role of absorptive capacity. International journal of information management, 46, 93-103.

Chang, H. H., \& Chen, S. W. (2009). Consumer perception of interface quality, security, and loyalty in electronic commerce. Information \& management, 46(7), 411-417.

Chen, J. V., Chen, Y., \& Capistrano, E. P. S. (2013). Process quality and collaboration quality on B2B e-commerce. Industrial Management \& Data Systems, 113 (6), 908926 
Chen, J. V., Jubilado, R. J. M., Capistrano, E. P. S., \& Yen, D. C. (2015). Factors affecting online tax filing-An application of the IS Success Model and trust theory. Computers in Human Behavior, 43, 251-262.

Chen, Y., \& Lin, Z. (2020). Business Intelligence Capabilities and Firm Performance: A Study in China. International Journal of Information Management, 102232.

Choi, W., Rho, M. J., Park, J., Kim, K. J., Kwon, Y. D., \& Choi, I. Y. (2013). Information system success model for customer relationship management system in health promotion centers. Healthcare informatics research, 19(2), 110.

Chou, J. S., \& Hong, J. H. (2013). Assessing the impact of quality determinants and user characteristics on successful enterprise resource planning project implementation. Journal of Manufacturing Systems, 32(4), 792-800.

Cidral, W. A., Oliveira, T., Di Felice, M., \& Aparicio, M. (2018). E-learning success determinants: Brazilian empirical study. Computers \& Education, 122, 273-290.

Costa, C. J., Aparicio, M., \& Raposo, J. (2020). Determinants of the management learning performance in ERP context. Heliyon, 6(4), e03689.

Davis, F. D. (1989). Perceived usefulness, perceived ease of use, and user acceptance of information technology. MIS quarterly, 319-340.

Debortoli, S., Müller, O., \& vom Brocke, J. (2014). Comparing business intelligence and big data skills. Business \& Information Systems Engineering, 6(5), 289-300.

Dedić, N., \& Stanier, C. (2016, December). Measuring the success of changes to existing business intelligence solutions to improve business intelligence reporting. In International conference on research and practical issues of enterprise information systems (225-236). Springer, Cham.

DeLone, W. H., \& McLean, E. R. (1992). Information systems success: The quest for the dependent variable. Information systems research, 3(1), 60-95.

Delone, W. H., \& McLean, E. R. (2003). The DeLone and McLean model of information systems success: a ten-year update. Journal of Management Information Systems, 19(4), 9-30.

DeLone, W. H., \& McLean, E. R. (2016). Information systems success measurement. Foundations and Trends® in Information Systems, 2(1), 1-116. 
Djong, F. D. B., Kamdjoug, J. R. K., \& Wamba, S. F. (2018, March). Information Technology Determinants of Organizational Performance in the Context of a Cameroonian Electricity Company. In World Conference on Information Systems and Technologies (934-941). Springer, Cham.

El-Adaileh, N. A., \& Foster, S. (2019). Successful business intelligence implementation: a systematic literature review. Journal of Work-Applied Management, 11 (2), 121-132.

Floropoulos, J., Spathis, C., Halvatzis, D., \& Tsipouridou, M. (2010). Measuring the success of the Greek taxation information system. International Journal of Information Management, 30(1), 47-56.

Gaardboe, R., Nyvang, T., \& Sandalgaard, N. (2017). Business intelligence success applied to healthcare information systems. Procedia computer science, 121, 483-490.

Gable, G. G., Sedera, D., \& Chan, T. (2008). Re-conceptualizing information system success: The IS-impact measurement model. Journal of the Association for Information Systems, 9(7), 18.

Gharaibeh, M. K, \& Gharaibeh, N. K. (2020). An empirical study on factors influencing the intention to use mobile learning. Advances in Science, Technology and Engineering Systems Journal, 5 (5), 1261-1265.

Ghobakhloo, M., \& Tang, S. H. (2015). Information system success among manufacturing SMEs: case of developing countries. Information Technology for Development, 21(4), 573-600.

Gonzales, R., \& Wareham, J. (2019). Analysing the impact of a business intelligence system and new conceptualizations of system use. Journal of Economics, Finance and Administrative Science, 24 (48), 345-368

Gorla, N., \& Somers, T. M. (2014). The impact of IT outsourcing on information systems success. Information \& Management, 51(3), 320-335.

Gorla, N., Somers, T. M., \& Wong, B. (2010). Organizational impact of system quality, information quality, and service quality. The Journal of Strategic Information Systems, 19(3), 207-228.

Hua, L. Y., Ramayah, T., Ping, T. A., \& Jun-Hwa, C. (2017). Social media as a tool to help select tourism destinations: The case of Malaysia. Information Systems Management, 34(3), 265-279. 
Ifinedo, P., Rapp, B., Ifinedo, A., \& Sundberg, K. (2010). Relationships among ERP post-implementation success constructs: An analysis at the organizational level. Computers in Human Behavior, 26(5), 1136-1148.

Jeyaraj, A. (2020). DeLone \& McLean models of information system success: Critical meta-review and research directions. International Journal of Information Management, 54, 102139.

Khatibi, V., Keramati, A., \& Shirazi, F. (2020). Deployment of a business intelligence model to evaluate Iranian national higher education. Social Sciences \& Humanities Open, 2(1), 100056.

Kulkarni, U. R., Ravindran, S., \& Freeze, R. (2006). A knowledge management success model: Theoretical development and empirical validation. Journal of management information systems, 23(3), 309-347.

Le, Q. B., Nguyen, M. D., Bui, V. C., \& Dang, T. M. H. (2020). The Determinants of management information systems effectiveness in small-and medium-sized enterprises. The Journal of Asian Finance, Economics, and Business, 7(8), 567-576.

Lim, Y. Y., \& Teoh, A. P. (2020). Realizing the strategic impact of business intelligence utilization. Strategic Direction, 36 (4), 7-9.

Lutfi, A., Al-Okaily, M., Alshirah, M. H., Alshira'h, A. F., Abutaber, T. A., \& Almarashdah, M. A. (2021). Digital Financial Inclusion Sustainability in Jordanian Context. Sustainability, 13(11), 6312.

Lutfi, A., Al-Okaily, M., Alsyouf, A., Alsaad, A., \& Taamneh, A. (2020). The impact of AIS usage on AIS effectiveness among Jordanian SMEs: A Multi-group Analysis of the Role of Firm Size. Global Business Review.

Martono, S., Nurkhin, A., Mukhibad, H., Anisykurlillah, I., \& Wolor, C. W. (2020). Understanding the Employee's Intention to Use Information System: Technology Acceptance Model and Information System Success Model Approach. The Journal of Asian Finance, Economics and Business (JAFEB), 7(10), 1007-1013.

Niño, H. A. C., Niño, J. P. C., \& Ortega, R. M. (2020). Business intelligence governance framework in a university: Universidad de la costa case study. International Journal of Information Management, 50, 405-412. 
Park, I., Sharman, R., Rao, H. R., \& Upadhyaya, S. (2009, December). On the Two Factors Affecting Information Systems Success in the Extreme Event Context. In Workshop on E-Business (181-185). Springer, Berlin, Heidelberg.

Pérez-Mira, B. (2010). Validity of DeLone and McLean's Model of Information Systems success at the web site level of analysis. USA: Doctoral Dissertation, Louisiana State University.

Petter, S., DeLone, W., \& McLean, E. (2008). Measuring information systems success: models, dimensions, measures, and interrelationships. European journal of information systems, 17(3), 236-263.

Pham, Q. T., Tu K. M., Sanjay M., Broderick C. \& Ricardo S. (2016). Critical success factors for implementing business intelligence system: Empirical study in Vietnam. In International Conference on Computational Science and Its Applications, 567-584. Springer, Cham.

Pitt, L. F., Watson, R. T., \& Kavan, C. B. (1995). Service quality: a measure of information systems effectiveness. MIS quarterly, 173-187.

Rana, N. P., Dwivedi, Y. K., Williams, M. D., \& Weerakkody, V. (2015). Investigating success of an e-government initiative: Validation of an integrated IS success model. Information Systems Frontiers, 17(1), 127-142.

Ranjbarfard, M., \& Hatami, Z. (2020). Critical Success Factors for Implementing Business Intelligence Projects (A BI Implementation Methodology Perspective). Interdisciplinary Journal of Information, Knowledge, and Management, 15, 175-202.

Roy, S. K., \& Balaji, M. S. (2015). Measurement and validation of online financial service quality (OFSQ). Marketing Intelligence \& Planning, 33 (7), 1004-1026.

Sabherwal, R., Jeyaraj, A., \& Chowa, C. (2006). Information system success: Individual and organizational determinants. Management Science, 52(12), 1849-1864.

Seddon, P. B. (1997). A respecification and extension of the DeLone and McLean model of IS success. Information systems research, 8(3), 240-253.

Seddon, P., \& Kiew, M. Y. (1996). A partial test and development of DeLone and McLean's model of IS success. Australasian Journal of Information Systems, 4(1). 
Torres, R., \& Sidorova, A. (2019). Reconceptualizing information quality as effective use in the context of business intelligence and analytics. International Journal of Information Management, 49, 316-329.

Urbach, N., \& Müller, B. (2012). The updated DeLone and McLean model of information systems success. In Information systems theory (1-18). Springer, New York, NY.

Urbach, N., Smolnik, S., \& Riempp, G. (2010). An empirical investigation of employee portal success. The Journal of Strategic Information Systems, 19(3), 184206.

Villamarín, J. M., \& Diaz Pinzon, B. (2017). Key success factors to business intelligence solution implementation. Journal of Intelligence Studies in Business, 7(1), 48-69.

Villamarín-García, J. M. (2020). Contributions from organisational collaboration to business intelligence solutions success. International Journal of Business Information Systems, 33(1), 103-131.

Visinescu, L. L., Jones, M. C., \& Sidorova, A. (2017). Improving decision quality: the role of business intelligence. Journal of Computer Information Systems, 57(1), 58-66.

Wang, Y. S. (2008). Assessing e-commerce systems success: a respecification and validation of the DeLone and McLean model of IS success. Information systems journal, 18(5), 529-557.

Wibowo, A., \& Sari, M. W. (2018). Measuring enterprise resource planning (ERP) systems effectiveness in Indonesia. Telkomnika, 16(1), 343-351.

Wu, J. H., \& Wang, Y. M. (2006). Measuring KMS success: A respecification of the DeLone and McLean's model. Information \& Management, 43(6), 728-739.

Yan Xin, J., Ramayah, T., Soto-Acosta, P., Popa, S., \& Ai Ping, T. (2014). Analyzing the use of Web 2.0 for brand awareness and competitive advantage: An empirical study in the Malaysian hospitability industry. Information Systems Management, 31(2), 96-103.

Yuthas, K., \& Young, S. T. (1998). Material matters: Assessing the effectiveness of materials management IS. Information \& management, 33(3), 115-124. 